\title{
From Thugs to Victims: Dakxin Bajrange Chhara's Cinema of Justice
}

Open-Access (Uncorrected) Preprint Version

\section{Do Not Cite!}

Forthcoming in Visual Anthropology Vol. 24, No. 3. May 2011

P. Kerim Friedman

Assistant Professor

National Dong Hwa University

Department of Indigenous Cultures

No. 1, Sec. 2, Da Hsueh Rd.,

Shoufeng, Hualien 97401

Taiwan

Acknowledgements: Thanks to Shashwati Talukdar for help with the translations. 


\section{From Thugs to Victims: Dakxin Bajrange}

\section{Chhara's Cinema of Justice}

\section{P. Kerim Friedman *}

The documentary films of Indian filmmaker Dakxin Bajrange Chhara focus, not on his own community, but on marginalized nomadic communities within his home state of Gujarat. In order to understand these films I draw on Partha Chatterjee's theory of "political society" to argue that Bajrange's portrayal of the social injustices directed against these other communities serves also to challenge the historical stigma his own community feels as a result of having been labeled a "Criminal Tribe" by the British. By highlighting the victimhood of India's Denotified and Nomadic Tribes (DNTs), Bajrange seeks to embue them with the "moral attributes of a community."

\section{THE MORAL ATTRIBUTES OF A COMMUNITY}

Before meeting Dakxin Bajrange Chhara for the first time in January of 2005, I only knew two things about him: One, that he was one of the creative forces behind Budhan Theatre, an activist street theater troupe whose powerful play Budhan [Bajrange 2002] I had seen in footage (filmed by my wife) of their 2000 performance in Bhopal. And two, that he had recently been released from police custody due to public outcry at his arrest. His arrest, in 2004, on what were widely believed to be trumped up charges, was seen as an attempt to silence Budhan Theatre's stinging critique of police brutality. We had come to Chharanagar with the hopes of making a film which

* P. Kerim Friedman is assistant professor in the Department of Indigenous Culture at National Dong Hwa University, Taiwan where he teaches visual and linguistic anthropology. He is also a filmmaker and co-founder of the group anthropology blog Savage Minds. E-mail: kerim.friedman@oxus.net 
would bring wider attention to these abuses. But our initial meeting with the volunteers of Budhan Theatre (as the actors are called) ended abruptly. It was late at night and some hooligans attempted to start a fight outside the cramped community library where the meeting was being held. Our hosts quickly whisked us back to our hotel. Later it was explained that they believed the fight had been staged by Budhan Theatre's opponents as a pretense to allow the police to break up the meeting. Over the next four years what had started as a small project to bring attention to the arrest of an activist [Talukdar and Friedman 2006] turned into a larger attempt to document the role of Budhan Theatre in Chharanagar (Talukdar and Friedman forthcoming). This period coincided with Bajrange's emergence as an important documentary filmmaker in his own right. Starting with his first film in 2005, through his third one in 2008, Bajrange's films have garnered him national and international attention as a powerful cinematic voice. This paper is an exploration of these films.

In order to understand the documentary films of director, actor, and playwright Dakxin Bajrange Chhara, it is necessary to understand the role Budhan Theatre plays in Chharangar, an urban ghetto on the outskirts of Ahmedabad, one of India's wealthiest cities. Labeled as a "Criminal Tribe" by the British, the stigma of criminality continues to hamper Budhan Theatre's attempts at establishing legitimacy for themselves and for their community. They live under constant threat of police harassment. Every one of Budhan Theatre's volunteers, indeed almost everyone we spoke to in Chharanagar, related stories involving bribery, arbitrary detention, false cases, and physical abuse. And yet, despite such pressures (or because of them?) Budhan Theatre has emerged as a powerful voice not just for their own community, but for all of India's sixty million [Devy 2004] Denotified and Nomadic Tribes (DNTs), as those once labeled "Criminal Tribes" are now known.

Partha Chatterjee argues that communities like the Chhara are treated by the state, not as "citizens," but as "populations." Populations are defined by marginal or illegal behaviors, the 
legitimacy of which can never be granted by the state [Chatterjee 2008:40]. For this reason, in dealing with such populations the state adopts "older ethnographic concepts ... as convenient descriptive categories for classifying groups of people into suitable targets for administrative, legal, economic, or electoral policy" [Chatterjee 2008:37]. Indeed the category of "Criminal Tribe" is such an ethnographic concept. Although disowned after the British left, the category remains active in shaping contemporary state policy towards the Chhara. Being defined as a population limits the ability of the Chhara to participate fully in civil society. As a result, I argue that Budhan Theatre functions as what Chatterjee calls a "political society" [Chatterjee 2008:36]. Political societies respond to state policy and exclusion from civil society by seeking "to give the empirical form of a population group the moral attributes of a community" [Chatterjee 2008:57]. I believe this is exactly what Bajrange is doing when he asserts that one of the goals of Budhan Theatre is to "to sensitize mainstream society, legal system, and the judiciary that we are not 'Born Criminals' but we are 'Born Actors'" [Seetha and Muralikrishna 2007].

Based on nearly eighty hours of interviews collected between 2005 and 2008 while working on our two documentary films about Budhan Theatre, this paper argues that we can only properly understand Bajrange's documentary films when we see them as a part of Budhan Theatre's efforts to transform itself from a political society to part of civil society. Accordingly, Bajrange's films serve a double purpose. First, they seek to define the DNT as a population, thus linking the Chhara with the plight of other marginalized communities in Gujarat and throughout India. And second, by focusing on the ways in which these communities are victimized, they seek to imbue all DNT populations-including their own-with the moral attributes of a community. It is therefore necessary to understand the historical construction of DNTs as a population, and the "older ethnographic concepts" which are responsible for that construction. Beginning with a brief history of how the category of Criminal Tribes emerged under colonial rule, I then explore how Bajrange's biography shaped his artistic and political development up to the founding of Budhan 
Theatre, the subsequent development of which is laid out in the following section. Finally, there is a detailed discussion of each of Bajrange's three documentary films. These films established Bajrange as one of India's leading indigenous filmmakers, and in my conclusion I draw on the work of Anna Tsing [2000] to explore how Bajrange's films serve to define the category of DNTs on a national scale.

\section{SLEEMAN'S LEGACY ${ }^{1}$}

Bernard Cohn identified various "investigative modalities" which shaped the construction of colonial knowledge/power, of these, one is what he calls the "the surveillance modality," which he defines as "special instrumentalities" constructed by the british "to control those defined as beyond civil bounds, and carried out special investigations to provide the criteria by which whole groups would be stigmatized as criminal" [Cohn 1996:11]. The widespread use of this modality in India can be traced back to William Sleeman's campaign against the Thuggees. In the years between 1826 and 1848 4,500 men were tried for "Thug crimes" and "a total of 504 - or nearly one in every nine - was hanged," while most of the remaining were transported to penal colonies, sentenced to life in prison, or perhaps "died in prison while awaiting trial" [Dash 2006:254]. Only a handful were acquitted. Just what were these thousands of men accused of?

The thugs ... were a cult of professional stranglers who preyed on travelers-though never on Englishmen-as an act of worship to the popular Hindu goddess Kali. They were represented as hereditary killers drawn from all regions, religions, classes, and castes, united by their devotion to Kali and the act of strangulation [Roy 1998]

There is considerable debate today about the extent to which such a phenomenon actually existed, or to what extent it was a product of the colonial imagination [Dash 2006; Roy 1998; van Woerkens 2002; Wagner 2004]. Yet Thuggee scholars and revisionists alike agree that the crimes were not religiously motivated as Sleeman was led to believe, and has been preserved in 
accounts from contemporary popular culture, such as The Deceivers and Indiana Jones and the Temple of Doom [Dash 2006:228; Roy 1998; Schwarz 2010; van Woerkens 2002:282-283; Wagner 2004:954]. Nor is the suggestion that the colonial government invented the Thuggee unique to contemporary postcolonial scholarship. At one point "the (colonial) government went as far as removing a judge from his post because he claimed thuggee did not exist and refused to cooperate in the operations against them" [Wagner 2004:961].

Regardless of the factual basis for Sleeman's campaign, "the work of the Thagi (Thuggee) and Dacoity Department led to the formation of an archive of criminal ethnography", which in turn led to "the designation of increasing numbers of people as members of 'criminal tribes and castes"' [Cohn 1996:11]. The genre of criminal, or police ethnography was primarily concerned with detection, describing physical features, habits, weapons and modus operandi which would help colonial officers identify various Criminal Tribes, their status as criminals having already been determined. As with the Thuggees, there was a belief that the Criminal Tribes had the ability to blend in with the rest of society. "In the literature there are many descriptions of persons who appear to be ordinary, law-biding subjects but who conceal a hardened and dangerous criminality" [Tolen 1991:111]. The Criminal Tribes were thought to copy the dress, manner, and even the speech of other castes, even taking up legitimate occupations, in order to "divert attention from their 'real' occupation, crime" [Tolen 1991:111].

The police ethnography therefore served as a sort of field guide to Criminal Tribes, describing the "modes of dress, deportment, disposition, habits, and mannerisms" [Tolen 1991:112] by which police could distinguish those with criminal tendencies from the honest subjects they sought to emulate. For this purpose books with titles like Notes on Criminal Tribes residing in, or frequenting the Bombay Presidency, Berar and the Central Provinces [Gunthorpe 1882], and, The history of railway thieves: with illustrations \& hints on detection [Naidu and Pauparao 1915] included seemingly random ethnographic details such as whether or not the 
women of a particular tribe were faithful to their husbands, or whether or not the tribe had a taste for jackal meat [Gunthorpe 1882:50,56]. As more and more groups were categorized as Criminal Tribes, district officers and policemen were increasingly expected to know the defining traits and cultural practices of "not just for one tribe but for perhaps a dozen or more" [Brown 1999:217]. Under such circumstances having access to some distinguishing criteria was more important than the quality of the ethnographic data upon which those criteria had been established. Little did it matter that the data consisted, in some cases, of "purely apocryphal" origin stories [1999:212] and recycled administration reports dating back to the 1860s [1999:217].

Central to these accounts was the practice of assigning a unique modus operandi to each tribe. In addition to describing what weapons they might or might not use, and their usual targets, the modus operandi would include information about their most common disguises. Here is an example from Lemarchand's 1915, A Guide to Criminal Tribes [Lemarchand 1915]:

Bhampta : Working in lots of three. Often disguise themselves as Marwadi or Hindu traiders, Lingayats, Jangam, Brahmans or shepherds. They are sometimes seen as minstrels, Sanadikorwas or Dakkhani Bhats. They are most commonly met with as Marathas. When posing as Gosains they add the suffix "das" to their names.

Little has changed since the British left. A 1999 article from the Indian Express describes the activities of the Modus Operandi branch of the police force in Southern Gujarat [Indian Express Newspapers 1999]. The reporters obtained the list used by the police to distinguish the various "gangs" active in the region, including "the Chaddi Banian Dhari, Dafer, Kevat, Waghris, Bawaris, Nats, Sansis, Shikliyar, Jhaver Thutho, (and) Chharras" [Express News Service 1999]. the Bawari gang is known to camp at railway stations before striking. They use the 'rumali' method, where they bend grills of houses to force their way inside. Other gangs like the Dafers and Chaddi Banian Dharis survey possible targets by posing as beggars, vendors and the like. Dafers are known to possess firearms but use these only when 
challenged. [Express News Service 1999]

This obsession with identification was recently taken up by Clare Anderson in a book length investigation of the various techniques used by the British to mark the bodies of convicts: clothing, tattooing, photography, and finally fingerprinting which was first used systematically by the colonial police in India, before being adopted by Scotland Yard [Anderson 2004].

As with police ethnography, the practice of cataloging and identifying criminals is still very much alive in Chharanagar. When we were filming in January of 2007 we had slowly been making progress in gaining the trust of the estimated fifteen percent of the community which still engages in thieving; however, just when the "merchants association" (vyapari mandal) representing the thieves had agreed to meet with us to discuss their participation in the documentary, our activities were interrupted by a series of police raids. The police were rounding up everyone suspected of thieving and photographing them and videotaping them at the police station. Chhara identified as thieves by the police were being documented whether or not they had ever been caught in an act of thieving. Young people with no criminal record fled the neighborhood and went into hiding to avoid being listed. While such police practices are no longer officially sanctioned, they are nonetheless still quite common in DNT communities.

In addition to Sleeman's legacy, the notion of Criminal Tribes also drew on Victorian concepts about the heritability of criminal behavior brought over from England. The slums of working class England "had hardened middle class attitudes towards the 'dangerous classes'" [Nigam 1990:156], but over time a distinction was made between "the criminal sections of the working class, on the one hand" and "industrious working men on the other" as a labor aristocracy began to bargain for their rights "within the bourgeois social order" rather than against the system as a whole [Nigam 1990:157]. This led, in the late 1860s, to the introduction in England of a range of measures "for the identification, treatment and control of criminal classes and habitual offenders" [Nigam 1990:158]. These practices were exported to the colonies 
and implemented in the Criminal Tribes Act (CTA) of 1871.

At first the CTA's scope was limited to a few communities in the North, but in 1911 the CTA was renewed and extended to the wondering tribes. On the urging of the Salvation Army, the new act added the concept of reformatory settlements to the existing regime of "daily reporting to the local officials, irregular roll calls, tickets of leave and punishments like fines, whipping and imprisonment" [Major 1999:669], many of these settlements were run by the Salvation Army itself. The Salvation Army's emphasis on reform through productive labor was profitable, especially since the CTA allowed settlement agencies to set their own wages [Radhakrishna 2001:77]. Workers from the settlements were also useful as strikebreakers [Radhakrishna 2001:77].

The Chhara weren't registered as a Criminal Tribe until 1933. The government's official justification for the settlement was that the Chhara had been a "menace to the city" [Symington 1937:3]. However, the history of the CTA suggests other possible motives. At a conference held in Southern India in 1916, the Settlement Officer for Criminal Tribes in Bijapur, O. H. B. Starte, discussed the advantages of building settlements near textile mills, which "afforded employment for men, women and children alike" [Radhakrishna 2001:111], but it was really Ahmedabad's mill owners, suffering from labor shortages and increased labor militancy who seemed to benefit the most from having a steady supply of laborers [Kamat 1998:72; Radhakrishna 2001:119]. Whatever the financial incentives there might have been to confine the Chhara, the ideology of the settlements was reform. As was the case with English workhouses around the same time, it was believed that "the moral value of disciplined labor" would have a transformative power over the inmates, allowing them to move to the Free Colony where they could rejoin society [Tolen 1991:119-120].

The CTA was finally repealed in Bombay State in 1949, and throughout the rest of India in 1952 [D' Souza 2001:78]. However, by the end of the 1950s, most states had replaced the CTA 
with Habitual Offenders Acts (HOAs), often using the exact same wording as the repealed CTA. As stated by a National Human Rights Commission report in 1998, the HOAs made possible "precisely the same avenues for mal-identification and persecution as the Criminal Tribes Act of 1871" [NHRC in D' Souza 2001:81]. And such abuses remain common to this day. DNT-RAG founder, Mahasweta Devi compiled a list of abuses for the years 1996 to 1998. The list includes numerous deaths in police custody, rape, torture, dismemberment, false charges, and lynchings [Devi 2002]. The 2004 arrest of Dakxin Bajrange Chhara is simply one of many such stories which continue to be reported throughout India.

\section{DAKXIN BAJRANGE CHHARA}

Bajrange's grandmother was a child when her family was captured and subjected to settlement life. She recounts being a young teenager in the Sholapur settlement when a widower from the Ahmedabad settlement bribed the officials to arrange a marriage over her family's objections. There is a scene in our film, Acting Like a Thief [Talukdar and Friedman 2006], where, asked by her grandson whether, in their life before the settlement, they were artists or thieves, she replies: "Artists. Artists, and also thieves. Do you understand?" She is proud of her father's skill as a thief, describing how he could steal the blanket off of you even as you slept. In later interviews she describes how her father, who came to live with her in Ahmedabad, was killed by the settlement officials when asking permission to go outside. All their movements were observed. Even, she says, going to the bathroom. And yet, there is also a certain amount of pride in their ability to evade such detection when it suited them. Her husband occasionally found work in the textile mills, but food was scarce and the two of them often found it necessary to steal in order to make ends meet.

As Bajrange's discussion with his grandmother shows, the Chhara's legacy as artists is not so easily disentangled from that of thieving. Indeed, while we were filming, members of Budhan 
Theatre often commented on the fact that thieving is a kind of acting. One volunteer told us, this is in our blood because before when people used to go out for stealing or to beg, they used acting...so stealing is an art...when people go out stealing, they create a situation and they'll act in such a way that you'll get completely involved...

Although a strict code of secrecy prevented anyone from divulging the particulars of thieving practices, it was emphasized that Chhara thieves have never relied upon violence, relying instead upon distraction and deception, both of which require thieves to be good performers. So while the Chhara may have once made a living primarily as itinerant artists and performers, as Bajrange often claims, thieving too plays an important role in the troupe's conception of themselves as born actors.

Bajrange grew up in a neighborhood which had originally been built as a "Free Colony" for former residents of the Ahmedabad settlement who had been discharged or released under probation [Ghandy 1941:12-13]. Seventy-five years after the settlement was first built, the Chhara still face numerous hurdles in their attempts to participate in mainstream society. And even though the CTA was repealed in 1952, the Chhara are still subject to many of its harshest measures. Indeed, an estimated sixty percent of the approximately 15,000 people living in Chharanagar brew liquor, which is illegal in the dry state of Gujarat, and perhaps as many as twenty percent make a living as petty thieves [Faleiro 2005]. Yet access to state funded education, as well as money from lucrative liquor sales, have afforded new educational opportunities to the Chhara. The community boasts over a 120 lawyers and at least one judge. Because anyone who passes the national exams has the right to practice law, the Chhara don't face the same hurdles in that profession as they do in education or the business world, where the stigma of criminality still poses a seemingly insurmountable obstacle. (The lawyers joke that, living in Chharanagar, they have no shortage of clients!)

Bajrange was born to one of the wealthiest families in his neighborhood. Alok Gagdekar told 
us that "Dakxin was rich, like royalty. We would go to see his new jeans. They had servants, icecream. We never thought we'd work with him." One of nine brothers and sisters in a large extended family which includes over eighty-eight people in the neighborhood, Bajrange's father had high hopes for him. Each of his four son's were named after the points of the compass (Dakxin means South) in the hopes that they would travel far. Indeed, Bajrange's brother Uttar (North) is now pursuing a graduate degree in engineering at an American university, an unprecedented achievement for the Chhara community. Bajrange, however, did not do so well in school. His sister remembers him as being naughty and spoilt when he was young. After failing three times at the English-medium school he was switched to a less prestigious Gujarati-medium school. There he did better and despite dreams of making it in Bollywood, he succeeded in completing a BA in psychology, and even started attending graduate school before financial difficulties made further study impossible.

It is a common enough story in Chharanagar. Young people will tell you with pride the number of years of college they finished before dropping out, often for financial reasons. In Bajrange's case it was his father's debts which radically altered his family's fortunes. Bajrange's father had at times been a thief and had run a numbers game. Such activities are still common, but with Bajrange's generation new educational opportunities began to open up, and his father understood the importance of education for their future. This was true of all the parents we spoke to. Whether they worked as bootleggers or thieves, they all emphasized the importance of education for their children.

Bajrange's love of movies began early. He describes making pocket money by working for his aunt, brewing illegal liquor, which he would then spend at the local video store. He and his friends even began experimenting with films. As he says, "we didn't know what the hell we were doing but we would just photograph ourselves doing dramatic things." He later used this skill to start a small advertising business. But his filmmaking skills really developed when he got a job 
at the Tara cable channel run by well known dancer and social activist, Mallika Sarabhai. It was at Tara that Bajrange began to make documentary films on social issues, and he continues to collaborate with some of the crew members he met working there. But it is unlikely that Bajrange would have gotten a job at Tara if he hadn't first written and performed the play Budhan with the other members of Budhan Theatre.

\section{THEATER FOR COMMUNITY DEVELOPMENT}

Dakxin Bajrange was one of several young people who met with the founding members of the DNT Rights Action Group (DNT-RAG), Mahasweta Devi, Lakshman Gaekwad, and G. N. Devy, when they visited Chharanagar in 1998 [Devi 2000] It was also on that day that Bajrange decided to write his first play, Budhan [2002]. The play is about the case of Budhan Sabar who had died in police custody. With the support of the Bengali writer and activist Mahasweta Devi, a high court settlement was achieved in favor of Budhan's wife, Shyamoli-a defining moment in the birth of the DNT rights movement [D' Souza 2001:104-112]. But while the history of Budhan Theatre is intimately tied to that of the DNT rights movement, it would be a mistake to attribute the development of Budhan Theatre entirely to this fateful meeting. Not only were there precedents within the community for street theatre, as well as for Budhan Theatre's community development endeavors, there were also social pressures pushing Chhara youth into political society, both in it's progressive and reactionary forms.

Better educational opportunities and newfound wealth (some of which comes from bootlegging) are helping to lift the Chhara out of poverty, and much of the frustration we witnessed among the younger generation is aimed at the ways in which discrimination has prevented them from becoming full fledged members of Ahmedabad's middle class society. A Chhara woman with an MA degree in English literature was turned away from teaching jobs because school administrators worried that parent's would object to having a Chhara teach their 
children. Other Chharas reported being turned down for jobs because even though they seemed responsible, employers worried about the imagined threat posed by their Chhara relatives. A newspaper reporter's family was forced out of a downtown apartment (near a good school) because tenants objected to having Chhara neighbors.

That reporter was Roxy Gagdekar Chhara, one of two brothers whose father died from injuries sustained while in police custody. Their father had trained as a lawyer, but unable to make ends meet (or pay for his children's education at an expensive English-medium boarding school) had returned to illegal activities, running one of the largest and most successful liquor brewing establishments in Chharanagar. An educated man he had formed a group called the Reform Club which had a small library and met to discuss social issues, such as reforming the traditional panchayat system of self-government within the Chhara community. When Prem Prakash, an important Sindhi writer and poet based in Ahmedabad, was looking for actors to play the slaves in a local production of Badal Sircar's Spartacus [Raha 2004:449], he turned to the Reform Club. The play did very well and attracted both a large audience from the community as well as positive critical reviews from the press.

Roxy Gagdekar, his brother Alok, as well as Dakxin Bajrange, were all present when DNTRAG came to Chharanagar in 1998. They had already been seeking support for a library and community center when Mahasweta Devi asked them what their community needed (Roxy Gagdekar, personal communication). Inspired by the Reform Club, Budhan Theatre seeks to reform Chhara society from within as well as to transform how the Chhara and other DNTs are seen by the outside world. As Bajrange puts it, Budhan Theatre is a 'Theatre for Community Development' [Seetha and Muralikrishna 2007]. As such it fulfills an important intermediary role between the local community and the numerous NGOs which comprise a large portion of India's civil society. The community library has been central to Budhan Theatre's activities since the very beginning. This library, which moves from location to location depending on available 
space, is much more than an assortment of donated books: it is also an informal school, a community center, even a computer center out of which the children publish their own magazine, Bal Chhara. ${ }^{2}$ In addition to providing much needed tutoring, homework supervision, and a homeaway-from home to local children, the library is also a battle ground in a political fight over the hearts and souls of the younger generation. The right-wing organization Rashtriya Swayamsehvak Sangh (RSS) runs a parallel program for local children which serves as a recruiting grounds for their Hindu-nationalist ideology [Nussbaum 2008]. One young volunteer who had previously attended RSS meetings (when he was around ten or eleven years old) explained:

they instigate you against the Muslims...they say this country just belongs to Hindus...and they sing the song, that we'll build a temple...with a lot of fanfare...and we'll break the mosques with a lot of fanfare...and they make you sing these songs...so I didn't like it...

He told his dad about his discomfort and his father replied that he had "showed good judgement." It was his father who then brought him to Budhan Theatre.

The creative aspects of the theater is equally important for understanding how Budhan Theatre functions as a political society. On a purely practical level it opens up new opportunities outside the seemingly closed local job market. Two Budhan Theatre almuni (including Alok Gagdekar) have attended the National Drama School (NSD) in New Delhi, India's premier theater academy, and others have taught theater locally as well. Kalpana Gagdekar (Roxy's wife) has a career in the Gujarati film industry. These experiences then also feed back into the work of Budhan Theatre. Alok Gagdekar's experience at NSD has allowed the troupe to perform more traditional stage productions which, in turn, open up new economic opportunities for the troupe, which has recently begun doing paid performances. The money earned from these paid performances has allowed Budhan Theatre to begin offering a small stipend to its volunteers. This is not yet enough to function as a primary source of income, but it is a first step towards the 
professionalization of their activities. Professionalization is important because it helps ensure continuity as the first generation of volunteers begin to build careers outside of the theater. It also helps encourage the volunteers to continue their involvement with the theater-and by extension, with the community — even as new opportunities open up outside of Chharanagar.

Documentary filmmaking has been one of the principle ways in which Dakxin Bajrange has been able to professionalize his activities. He has also begun to publish his plays (Bajrange forthcoming). Although Bajrange is always careful to credit Budhan Theatre in both his films and his plays, the creative process involved in each is quite different. During our filming we had numerous opportunities to witness the creative process of Budhan Theatre. The process we saw being led and directed by Bajrange is improvisational and democratic. Bajrange writes up a treatment beforehand, but the movements and dialog are worked out with the actors during rehearsals. Although Bajrange endeavors to train Budhan Theatre volunteers to work on his films (some of whom gained experience working as crew on our film as well), his films bespeak a much more personal vision. In the discussion that follows I trace out what I believe to be a progression from a filmic voice which is closely modeled on his work in street theater, towards a more uniquely cinematic voice in his most recent documentary.

\section{THE FILMS: FIGHT FOR SURVIVAL}

Bajrange's first film as an independent documentary film maker, Fight for Survival [2005], relates to an incident which took place on September 5th, 2004. On that day, two members of the Madari community, a nomadic population who traditionally work as snake charmers, were returning from the annual cobra festival when they were stopped by a joint operation of the Animal Help Foundation and the state Forest Department. According to the film, the officials released their snakes (their main source of livelihood), beat them, locked them in a cage on the back of a truck with some other Madari prisoners, took them out and beat them again, disrupting 
a Madari settlement and beat people while making further arrests, threatened to give electric shocks to the original two victims (the shocks were never administered), and then locked them up for the night in a dog cage at the Animal Help Foundation headquarters. The incident was reported in the state newspaper, Gujarat Samachar, and the film shows news photos depicting their bruises. For the film Bajrange interviewed the victims, other members of the Madari community, representatives of the Animal Help Foundation and other animal rights activists, officials from the Forest Department, and the reporter who broke the story.

The film was funded by the Bhasha Publication and Research Center, and in an interview Bajrange informed me that the idea for the film originally came from Bhasha's director at the time, Dr. G N Devy. Initially intended to be a short five minute film, the film grew as it became clear that more time would be required to do justice to the complex issues involved. In making this film Bajrange insists he went to great lengths to show both sides of the story. While Bajrange told me that he wished to remain "neutral," letting the audience judge the ultimate truth for themselves, the film's central conceit, a dramatic reenactment of the events performed by the Madaris themselves and told from their point of view, clearly biases viewers in favor of the victim's story. Bajrange informed me that the idea of doing such a reenactment came from the Madaris themselves.

The film's dramatic reenactments are edited for greater effect with music, freeze frames, and repetition, highlighting the injustices alleged by the victims. Despite the heavy hand of such dramatic devices, Bajrange also manages to create space for the other side a chance to put forward their side of the story. G.S. Patel, a range officer with the Ahmedabad Forest Department distributes the blame by suggesting that any violence might have taken place after the Madaris refused to give up their snakes (their resistance thus provoking violence), and that the damage to the village was caused after the Madaris sought to flee the officers by hiding in the village, inciting the chase and destruction which followed. Rahul Sehgal, of the Animal Help 
Foundation, asserts that the victims spent the night in the kitchen after being served dinner, not in a dog cage as they claim (although he was not there personally at the time).

But the controversy in this film is only minimally over the facts of the case, as the activists and officials interviewed deny having any direct knowledge of the events, and mostly speak in more general terms about the conflict. Instead, the conflict focuses on the right of the Madari to practice their traditional craft, and the general question as to what means can be used to stop them. The film starts with three quotes, setting up this conflict. Ramnath Madari states that they would rather die than give up their snakes. Rahul Sehgal asks the director whether he is "happy that India is still portrayed as the land of snake charmers and elephants?" And AK Verma of the Indian Forest Service highlights the illegality of catching snakes, removing their fangs and poison glands, and taking them into areas where they are not allowed. The claim that the snakes themselves were harmed by the Madaris is disputed at the end of the film by Japan Pathak, the Gujarat Samachar reporter who broke the story, who says that the authorities had confirmed that the snakes which were caught had their fangs intact.

Neither the government officials nor the animal rights activists are portrayed as being particularly concerned about the well-being of the Madari, either in terms of their general livelihood or with regard to the specific harm that might have befallen them in this case. Whereas the quotes from government officials show them seeking to shift blame back on the Madari community, the quotes from activists show them viewing the incident primarily as a public relations debacle. Snehal Bhatt, an activist in the nearby city of Baroda asserts that

Experienced people like me, who have dealt with this for years, I never have problems, because I immediately start speaking against them [the Madaris], "How many days do you think this snake will survive? You tell me, you tell me." So what happens is that the public goes against the Madaris. Those who are new and haven't done this as often, when they go to catch them, the public starts to sympathize with the Madaris and go against 
us. $^{3}$

Although later she admits that she too has resorted to violence in dealing with the Madaris: "I am not going to lie to you. I also raise my hand sometimes."

The most critical statement in the film is by Rahul, who points to the role of the filmmaker in shaping public perception: "If you catch a drug peddler with drugs," he says, "then he is legally punishable, but if you wan to evoke sympathy for him, then do it, it is your job. And if you can't then you are not a successful documentary filmmaker." This scene introduces a striking moment of reflexivity [Ruby 1980] in an otherwise straightforward journalistic narrative. It also establishes Rahul Sehgal as a keen media observer and operator who pays close attention to the way public perception is shaped.

At one point in the film, in the middle of the dramatization of the beating, Bajrange shows a close-up of a newspaper story about the Indian railway minister, Laloo Prasad Yadav, giving permission to send Indian cows to slaughter houses in Bangladesh. The issue is also discussed in Rahul's interview. I asked Bajrange about the relevance of this issue to the case of the Madaris. His response was that this story showed that the animal cruelty law could be waved when large corporate interests were at stake, but when it is a marginal population like the Madaris, the law is enforced with a vengeance. In the film he puts the question of unequal enforcement to Rahul Sehgal, who denies that there is any reason to consider the two cases together.

As a nomadic tribe the Madari are now considered DNTs, even though they were not officially listed as a "Criminal Tribe" under the Bombay Presidency (which then included Gujarat) [Rao 2008]. I asked Bajrange about the similarities and differences between the Chhara and the Madari. He responded that because they had not been forcibly settled, the Madari remained a nomadic community, whereas the Chhara were now sedentary. He saw similarities, however, in their traditions-such as their panchayat system-and asserted a kinship with all nomadic communities because the Chhara had previously been nomadic and Bhantu-speaking 
populations (the language spoken by the Chhara) are still nomadic in other parts of India.

Another issue which comes up in the interview with Rahul is that of vegetarianism. Rahul is ambivalent, seeing many problems with treating vegetarianism as a legal issue. For instance, what would one do with animals currently raised for food after a ban on slaughter had been implemented? The question is important for the Chhara, who like the minority Muslim population, continue to eat meat. While we were filming our documentary, we encountered a discernible embarrassment and discomfort whenever filming animals being slaughtered (as is done during a traditional mourning ceremony). Part of this was their knowledge that I myself am a vegetarian, however it was also clear from our interviews that some upwardly mobile members of the younger generation of Chharas were embarrassed by this ritual slaughter, seeing it as a sign of the community's backwardness.

This issue can be seen as part of a larger battle being waged over the religious life of the Chharas. As we saw earlier, the Hindu right has been aggressively recruiting indigenous populations, including the Chhara, to identify as Hindus. These efforts have met with considerable success in the community. Asked about the frequent pilgrimages we witnessed setting out from Chharanagar, Bajrange's father told us:

now people are much more religious than they use to be...it's because people have more belief in god...earlier people just drank...and people just worried about making a living... and these days, everybody has a big temple in their house...

Budhan Theatre's attitude towards religion was more complicated. While they prayed before every performance and many members had temples in their own homes, they also emphasized the animistic and syncretic aspects of their traditional religious practices. Many still pray to Sufi saints, and we were told several times that Chharas "worship stones." As one volunteer put it: "you can spend on as much money as you want on a wedding but if you don't offer alcohol to a stone, then you're marriage won't be legitimate." By embracing these non-Hindu traditions, 
Budhan Theatre sought to challenge the discourses of Hindu nationalism.

\section{THE FILMS: BULLDOZER}

Bajrange's second film, Bulldozer, begins with the sound of the director's voice reading some lines from "The Most Dangerous Thing" by the well-known leftist poet, Pash (Avtar Singh Sandhu) [Sandhu 2009]. It is a poem about the dangers of complacency, of the gradual numbing of our hopes and dreams which takes place "between home and work." And indeed, Bajrange's movie aims (as do his plays) to shake us out of our complacency into action. The film's focus is the demolition two DNT settlements by the Ahmedabad Municipal Corporation. The film claims that, as a result of this dislocation, and subsequent exposure to the elements, twelve children died, their names filling up a blank screen. In the opening scene, shots of the Municipal Corporation's brick exterior are cut with shots of a child crying, his face full of snot and flies. The film ends with funeral pictures of the dead girl whose story motivated Bajrange to make the film.

While the film's message is powerful and direct, the narrative structure of the film is not. Indeed, the complex interweaving of street theater, interviews, voice overs, and verité footage is likely to confuse viewers who are not familiar with the events discussed in the film. Such confusion is understandable, since the film is in many ways closer to the street theater tradition in which Bajrange first made his name than it is to that of traditional documentary filmmaking.The film shares with street theater both its exaggerated dramatic style and a sense of immediacy. Indeed, throughout the film we see scenes from two street-side performances by Budhan Theater. The first from their adaptation of the Badal Sircar play Bhoma [1983], and the second from Budhan Theatre's original play "Mujhe Mat maro ... Sahab" ("Please don't beat me ... sir"), a play which is a medley of scenes from all of Budhan Theatre's plays, including the play Bulldozer from which the film gets its title. The haunting dirge-like song from that play runs 
as a refrain throughout the film.

The film grew out of the involvement of Budhan Theatre with campaigns on behalf of two different DNT communities living in the city of Ahmedabad. The first is a settlement in Maninagar made up of 191 families from the "Sansi, Rajbhoi, Vaghri and Dom tribes" (Gagdekar 2006a). In both 2006 and 2007, while making our film, we visited Maninagar with Bajrange, and personally saw the conditions in which the local population lived. Their homes, having been destroyed four times since 2004, are little more than temporary shelters, rigged up with cloth and string. There is no plumbing or electricity, except what can be diverted illegally. The population make their living selling maps, making synthetic rope and whigs, as well as working as day laborers. According to the law, any family settled in Ahmedabad since 1965 is guaranteed alternative housing if the city encroaches upon their land (Gagdekar 2006a). However, because of the high rates of poverty and illiteracy in the community, few of the residents have the necessary papers to prove long term residence. Attempts by activists to file Right to Information Act requests for government documents which might prove their residence have been repeatedly denied or delayed (Bajrange, personal communication). After a well publicized hunger strike in 2005 the city promised to provide housing to some of the residents, but failed to act on its promises. Eventually the matter came before the state supreme court which enacted a stay on the demolishment until alternative housing can be found for the community residents.

One thing everyone in Ahmedabad would know, but which is never explicitly discussed in the film, is that Maninagar is the home district of Gujarat's Chief Minister, Narendra Modi. Modi is a controversial figure who was denied a visa to the United States in 2005 over his suspected involvement in the 2002 Gujarati riots [India Times News Network 2005]. The challenge to the Municipal Corporation is therefore an indirect challenge to Modi and the ruling party in Gujarat. As an activist, Bajrange was at the forefront of the campaign to find new housing for the Maninagar residents, although his own involvement in the struggle (including the hunger strike) 
is not discussed in the film (Gagdekar 2006b).

The one time Modi's name is mentioned in the film is in relation to the second community, a DNT settlement outside of the Indian Institute of Management (IIM) whose world famous campus was designed by the renowned American architect, Louis Kahn. This settlement, with 250 families from the Bharthari, Rajbhoi, Nat Bajania and Harijans communities was initially disrupted when IIM began expanding to make way for a new campus (Gagdekar 2006c). The residents then camped on the street outside the walls of the new campus, only to have their temporary shelters destroyed in preparation for a visit by Modi and (then) president, Dr. A.P.J. Abdul Kalam, who were to arrive via that same road. One of the children who died from exposure is from this community. Community members also recount getting beaten during the demolition, one woman stating that her child was stillborn as a result of such a beating.

Bajrange's film punctuates each story of a child's death with a freeze-frame, during which the word "died" echoes three times. This dramatic repetition is rendered unnecessary by the power of the simple and direct testimony given by the grieving parents to the camera. Perhaps more effective is a scene from the play Bulldozer (performed as part of "Mujhe Mat maro ... $\left.S a a b^{\prime \prime}\right)$ in which the actress Kalpana Gagdekar enacts the grief of one of the mothers, declaring, to a swaddled doll,

My child is dead. You were just born from my womb. I hadn't named you yet. You should have allowed me to hug you and kiss you. Do you know? When the Municipality workers came ... Everyone ran with their belongings but I had to run with you in my womb, along with my belongings. My breast is full of maternal feelings. You should have allowed me to hug and kiss you. So many times I kept you safe in my womb, but I was unable to save you from this killer cold. My baby...

This is followed by the chorus singing, "Beautifying the cities... bulldozer... Shivering children in the cold... bulldozer... Mourn the death of four children... bulldozer..." as they surround 
Kalpana who falls to the ground crying, again, "My baby..."

Watching this scene on film, however, it is impossible not to compare it to the energy we felt when we witnessed such a performance performed live, across the street from the main entrance to IIM. Members of the displaced DNT community, including one of the couples who lost their child, sat on the side as Budhan Theatre performed "Mujhe Mat maro ... Saab." What stands out in my memory of this live performance was the interaction between the actors and the passing crowd. At the end of the performance each of the members of Budhan Theatre took a similarly swaddled doll, representing the babies who died, and handed it to someone in the audience. Watching the film version of Bulldozer one gets the feeling that Bajrange wishes to break the barrier between the screen and the audience in a similar way.

\section{THE FILMS: THE LOST WATER}

The title for Bajrange's third film, The Lost Water [2007] comes from a folk tale told in the Little Rann of Kutch, a desert the size of Delaware [Singh et al. 2007:765] in the North of Gujarat. According to the tale, the Agariyas are often seen digging in the desert, in search of lost water. While presented as a folk tale, it isn't far from the truth. Earning their meager living cultivating salt, the Agariyas must dig numerous wells before they find water, which might be brought in from kilometers away to flood the shallow salt pans. Once a part of the Arabian sea, the Little Rann is now dry, and efforts to pipe water from the sea (as was done under the British) were stalled due to opposition from the officials in charge of the Wild Ass Sanctuary which now occupies much of the region. In Bajrange's film we meet a worker who has dug nine wells to no avail. It takes about ten days to dig a well, and we learn of at least one Agariya who was killed by gas escaping a dry well.

The film depicts the life of the Agaryias, focusing on health issues and the exploitative conditions of their labor in the salt fields. They are paid around 15 to 17 rupees for a one hundred 
kilo bag of salt which will sell at the store for anywhere between two hundred to two hundred and fifty rupees. At the end of the day they rarely earn more than forty five rupees, less than half of the one hundred rupee a day minimum wage required by state law. The Agaryias also suffer from skin diseases as a result of working unprotected in the salt, blindness from the desert heat, and malnutrition from limited access to fresh vegetables and clean water. Government officials are interviewed as stating that protective clothing and medicine have been distributed to the Agaryias, but the people interviewed in the film deny ever having received such provisions.

The Lost Water is Bajrange's most gripping film, and it is the first one to receive international distribution. Bajrange's cameraman for all three films, Hemang Pathak, makes excellent dramatic use of the visually stunning scenery: the dry cracked soil, the wide salt pans, and the mountains of salt at the processing plant. Stark scenes of school kids singing folk songs in the desert give the film an almost surreal feeling. Compared with his earlier films, there is far less use of theatrical techniques, although there is one scene of a street play being performed at a nearby school. Still, there is in this film the same desire to make the audience see that which they might rather not wish to see. The camera freezes on open sores which are then highlighted with circles as the soundtrack plays the sound of a camera shutter. We look into the face of a sick boy who is too weak to swat the flies on his face as he sings a Bollywood tune. As with all of Bajrange's films, this film is meant to spur us into action.

\section{CONCLUSION}

Bajrange has stated that Budhan Theatre's plays aim to be "a cultural expression of all denotified tribes" [Seetha and Muralikrishna 2007], not just the Chhara. Indeed, the very name Budhan Theatre is notable for the bond it forges with the Kheria Sabar DNT community in West Bengal, over one thousand four hundred kilometers away from Chharangar. In choosing this name, Budhan Theatre has made a deliberate choice to identify not just as Chharas, but as members of 
the larger DNT community. This is remarkable because the category of DNT is still not widely used in India. Depending on the state, DNT communities might be found under various other categories by which marginalized populations are listed: Scheduled Tribes, Scheduled Castes, or Other Backward Classes. For this reason, Bajrange's three films, each of which focuses on the plight of various nomadic communities in his home state of Gujarat, can be seen as part of a project to construct the very category on whose behalf he wishes to speak. In fact, his planned fourth film, tentatively titled "Birth $1871,{ }^{, 4}$ is an ambitious documentary about the plight of DNTs in the states of Maharashtra, Madhya Pradesh, Gujarat and Rajasthan (possibly expanding to include Uttar Pradesh and West Bengal as well). The construction of these other DNT communities as victims is important not just as a call to for social justice, but also because the fact of their victimhood plays is central to the construction of DNTs as a population with the moral attributes of a community.

Putting this in another way we might call Bajrange's work a scale-making project [Tsing 2000:21], recasting DNTs as legitimate participants in a global human rights movement on the behalf of indigenous peoples as opposed to dangerous criminals whose movements must be subject to constant surveillance and control by the state. Anna Tsing's term "scale-making project" helps us make sense of Bajrange as an indigenous filmmaker. For one thing, indigenous communities are often defined in terms of scale. They are thought of as tied to a specific locality (despite the realities of urban migration patterns and the fact that some indigenous peoples are nomadic). For DNT communities there is a difference between those who were labeled as Criminal Tribes and forcibly settled under the British, and those who remain semi-nomadic to this day. Although the Chhara fall in the first category, Bajrange's films to date focus on those DNT communities who have no fixed place of residence. Secondly, indigenous people have often been defined by through "the construction of specific scales of social control" [Howitt 2007], such as the very concept of "tribe" [Mamdani 1996]. The very construction of DNTs as a 
category is a testament to the legacy of the technologies of knowledge/power first developed by the British, many of which remain in use today. And finally, "indigenous politics provides many examples of the harnessing of scale analysis to the purposes of social transformation" [Howitt 2007]. Bajrange's films are first and foremost the films of a social activist, but his activism is very much informed by the politics of indigeneity as defined by both the colonial experience of so-called "Criminal Tribes" as well as the rise of the DNT rights movement in the late nineteen nineties.

NOTES

\section{REFERENCES}

Anderson, Clare

2004 Legible Bodies : Race, Criminality, and Colonialism in South Asia. Oxford: New York, NY, USA

Brown, Mark

2003 Ethnology and Colonial Administration in Nineteenth-Century British India: The Question of Native Crime and Criminality. The British Journal for the History of Science 36(2):201-219.

Chatterjee, Partha

2008 The politics of the governed: Reflections on popular politics in most of the world. Contemporary Political Theory 7:114-119.

Cohn, Bernard S.

1996 Colonialism and Its Forms of Knowledge. Princeton: Princeton University Press.

D'Souza, Dilip

2001 Branded by Law: Looking at India's Denotified Tribes. New Delhi: Penguin 
Books.

Bajrange, Dakxin

2002 Budhan. In Painted Words: An Anthology of Tribal Literature. Devy G. N., ed. Sonal Baxi, trans. Pp. 260-285. New Delhi: Penguin Books.

Forthcoming Five Plays. Sonal Baxi, trans. Unpublished manuscript

Dash, Mike

2006 Thug: the true story of India's murderous cult. Granta Books.

Devi, Mahasweta

2000 Badge of all their tribes. Times of India, January 5. Electronic document, http:// www.lib.virginia.edu/area-studies/mahasweta/badge.html, accessed November 2, 2009.

2002 Year of birth - 1871. India Together. Electronic document, http://www.indiatogether.org/bhasha/budhan/birth1871.htm, accessed November 2, 2009.

Devy, Ganesh N.

2004 Adivasis Legal Provisions, Languages, Locations: a Reference Document for the Status of Adivasis and Denotified and Nomadic Jatis in India. Ganesh Devy, ed. Vadodara, India: Adivasi Academy and Bhasha Research \& Publication Centre.

Faleiro, Sonia

2005 "Thieves Who Steal a Chance in Life." Tehelka. November 26. Electronic document, http://www.tehelka.com/story_main15.asp?

filename $=$ hub112605thieves_who.asp, accessed November 2, 2009.

Foucault, Michel

1980 Truth and Power. In Power/Knowledge: Selected Interviews and Other 
Writings, 1972-1977. New York: Pantheon Books.

Friedman, Kerim P.

2007a "Colonial Ethnography." Savage Minds. Electronic document, http://savageminds.org/2007/12/18/colonial-ethnography/, accessed December $18,2007$.

2007b "Thuggee." Savage Minds. Electronic document, http://savageminds.org/2007/12/22/thuggee/, accessed December 22, 2007.

Gagdekar, Roxy

2006a Ahmedabad municipal corporation is even dangerous than the killer quake of Gujarat. Roxy Gagdekar. Electronic document, http://roxygagdekar.blogspot.com/2006/01/ahmedabad-municipal-corporationis_03.html, accessed July 17, 2008.

$2006 \mathrm{~b}$ Struggle of three years resulted in allotment of six houses to Sansis. Roxy Gagdekar. Electronic document, http://roxygagdekar.blogspot.com/2006/01/struggle-of-three-years-resultedin.html, accessed July 17, 2008.

2006c The negative reaction of a protest play 'Mujhe Mat Maro Saab' by Budhan Theatre. Roxy Gagdekar. Electronic document, http://roxygagdekar.blogspot.com/2006/01/negative-reaction-of-protestplay.html, accessed July 17, 2008.

Ghandy, P. J.

1941 Annual Administration Report on the Working of the Criminal Tribes Act in the Province of Bombay. Bombay: Government Central Press.

Gunthorpe, Edward J.

1882 Notes on Criminal Tribes Residing in or Frequenting the Bombay Presidency, 
Berar, and the Central Provinces. Times of India: Bombay.

Howitt, R.

2007 Scale. In A Companion to Political Geography. John Agnew, Katharyne

Mitchell, Gerard Toal, eds. Pp. 138-157. Wiley-Blackwell.

Indian Express Newspapers

1999 Superstitions give gangs away. Indian Express Newspapers (Bombay), May 19.

Electronic document,

http://www.indianexpress.com/res/web/pIe/ie/daily/19990519/ige19151.html, accessed: July 17, 2008.

India Times News Network

2005 No entry for Modi into US: Visa denied. The Times of India, March 18.

Electronic document, http://timesofindia.indiatimes.com/articleshow/msid-

1055543, curpg-1.cms, accessed November 2, 2009.

Kamat, Manjiri N.

1998 The War Years and the Sholapur Cotton Textile Industry. Social Scientist 26(1112): $67-82$

Lemarchand, Alfred Eric Maitland

1915 A Guide to Criminal Tribes. Gort Press: Nagpur.

Major, Andrew J.

1999 State and criminal tribes in colonial punjab: Surveillance, control and reclamation of the“dangerous classes”. Modern Asian Studies 33(3): 657² 688.

Mamdani, Mahmood

1996 Citizen and Subject. Princeton: Princeton University Press.

Naidu, Pauparao M.

1915 The History of Railway Thieves: with Illustrations \& Hints on Detection. 
Madras: Higginbothams.

Nigam, Sanjay

1990 Disciplining and Policing the “Criminals by Birth, ${ }^{\circ}{ }^{\circledR}$ Part 1: The Making of a Colonial Stereotype-- The Criminal Tribes and Castes of North Iindia. Indian Economic and Social History Review 27(2):131-164.

Nussbaum, Martha

2008 The Clash Within: Democracy, Religious Violence, and India's Future.

Cambridge, MA: Harvard University Press.

Radhakrishna, Meena

2001 Dishonoured by History: "Criminal Tribes" and British Colonial Policy. Hyderabad: Orient Longman.

Raha, Kironmoy

2004 Badal Sircar. In The Oxford Companion to Indian Theatre. Ananda Lal, ed. Pp. 448-449. New Delhi: Oxford University Press.

Rao, Raghvendra

2008 "Panel favours reservation for nomadic tribes." Indian Express Newspapers (Bombay), August 21. Electronic document, http://www.indianexpress.com/news/panel-favours-reservation-for-nomadictribes/351413/0, accessed: November 9, 2009.

Roy, Parama

1998 Discovering India, Imagining Thuggee. In Indian Traffic: Identities in Question in Colonial and Postcolonial India. University of California Press. Electronic document, http://ark.cdlib.org/ark:/13030/ft8s20097j/, accessed July 17, 2008.

Ruby, Jay

1980 Exposing yourself: Reflexivity, anthropology and film. Semiotica 3(1-2):153- 
179.

Sandhu, Avtar Singh (Pash)

2009 The most dangerous thing, Translated by Suresh Sethi. Electronic document, http://www.literatureindia.com/2009/10/14/the-most-dangerous-thing/, accessed November 8, 2009.

Schwarz, Henry

2010 Constructing the Criminal Tribe in Colonial India: Acting Like a Thief. Oxford: Wiley-Blackwell.

Seetha, B. T. and Muralikrishna C.

2007 Seetha BT: Budhan, the third theatre. Muse India 14(July-August). Electronic document, http://www.museindia.com/showfeature3.asp?id=670, accessed July $17,2008$.

Sarina Singh, Joe Bindloss, Rafael Wlodarski, Amy Karafin, Paul Harding, Lindsay Brown, Mark Elliott, Simon Richmond, Virginia Jealous, and Tom Spurling 2007 India (Country Guide). Lonely Planet.

Sircar, Badal

1983 Three Plays: Procession, Bhoma, Stale News. Samik Bandhyopadyay, trans. Calcutta: Seagull Books.

Symington, D.

1937 Annual Administration Report on the Working of the Criminal Tribes Act in the Bombay Presidency. Bombay: Government Central Press.

Tolen, Rachel J.

1991 Colonizing and Transforming the Criminal Tribesman: The salvation Army in British India. American Ethnologist 18(1):106-125. 
2000 The global situation. Cultural Anthropology 15(3):327-360.

van Woerkens, Martine

2002 The Strangled Traveler: Colonial Imaginings and the Thugs of India. Chicago: University Of Chicago Press.

Wagner, Kim A.

2004 The deconstructed stranglers: A reassessment of thuggee. Modern Asian Studies 38(04):931-963.

FILMOGRAPHY

Bajrange, Dakxin

2005 Fight for Survival: A Film from Bhasha. DVD. Bhasha Research and Publication Center.

2006 Bulldozer. http://budhantheatre.org/films/bulldozer/, accessed July 17, 2008.

2008 The Lost Water. DVD, color, 21 min. Budhan Theatre.

Talukdar, Shashwati, and P. Kerim Friedman

2006 Acting Like a Thief. DVD. : Documentary Educational Resources.

Forthcoming Please Don't Beat Me Sir. 
1 Some parts of this section developed out of posts I wrote on the anthropology blog, Savage Minds (Friedman 2007a; 2007b)

2 My wife and I, together with our producer Henry Schwarz, have started a 501(c)3 non-profit, Vimukta Inc. which currently helps support the activities of the Budhan Theatre library. For more information visit http://vimukta.org

3 Due to the poor quality of the English subtitling in Bajrange's films, all quotes from those films have been modified with reference to the original Hindi by Shashwati Talukdar.

4 The title was by Mahasweta Devi's article "Year of birth - 1871" [2002]. 